\title{
Relationship between coproparasitological and hematological examinations of Cuniculus paca in captivity
}

\section{Relação entre exames coproparasitológicos e hematológicos de Cuniculus paca em cativeiro}

\author{
Breno Kalyl Freitas Nascimento ${ }^{1 *}$; Vânia Maria França Ribeiro²; Vanessa Lima \\ da Silva ${ }^{3}$; Patricia Santos Ferreira Peruquetti²; Soraia Figueiredo de Souza ${ }^{2}$; \\ Patrícia Fernandes Nunes da Silva Malavazi ${ }^{4}$
}

\begin{abstract}
The objective of this study was to conduct coproparasitological examinations and hemoparasite investigations associated with a hemogram to evaluate the state of the parasitized animals before and after deworming, contribute to sanitary measures, and provide knowledge of Cuniculus paca hematological patterns. We performed these examinations in 20 animals aged between 2 and 10 years on different dates (day 0 and day 30) before and after deworming with a vermifuge based on albendazole + cobalt. The changes caused by endoparasites and hemoparasites were observed and whether there was a satisfactory effect on deworming was evaluated. Trichuris spp., Strongyloides spp., and nonsporulated Eimeria spp. oocytes were detected during the examinations. Trichuris spp. had the highest incidence. We found no hemoparasites in any blood smears. In the first sampling, the eosinophilia and leukocytosis in the hemogram indicated parasitism in the animals. In the second sampling, the number of eosinophils decreased and the number of eggs and oocysts nearly disappeared in the coproparasitological examinations. The vermifuge showed an acceptable effect on sanitary management, and the hemogram was consistent with animal hygiene.
\end{abstract}

Key words: Wild animal. Endoparasites. Blood count.

\section{Resumo}

O presente experimento foi realizado com o intuito de efetuar exames coproparasitológicos e pesquisas de hemoparasitas associados a hemograma, como forma de avaliação do estado dos animais parasitados, antes e após a desverminação de maneira que, se possa contribuir com as medidas sanitárias além de, proporcionar conhecimentos de padrões hematológicos das pacas (Cuniculus paca). Os exames foram realizados em 20 animais, com idades variadas ( 2 a 10 anos) em datas distintas (Dia 0 e dia 30), antes e após desverminação, com vermífugo a base de albendazol + cobalto, com a ideia de observar possíveis alterações ocasionadas por endoparasitas e hemoparasitas e se houve efeito satisfatório na desverminação dos animais. Foi então observado a presença de Trichuris spp., Strongyloides spp., oocistos de Eimeria spp. não esporulados, nos exames, sendo Trichuris spp. o de maior incidência. Não foi encontrado em nenhum esfregaço sanguíneo hemoparasitas. Eosinofilia e leucocitose presente

1 Discente, Curso de Mestrado, Programa de Pós-Graduação Sanidade e Produção Animal Sustentável na Amazônia, Universidade Federal do Acre, UFAC, Rio Branco, AC, Brasil. E-mail: breno_kalyl@hotmail.com

2 Prof ${ }^{\text {as }} \mathrm{Dr}^{\text {as }}$, UFAC, Rio Branco, AC, Brasil. E-mail: vania.rib@uol.com.br; pperuquetti@gmail.com; soraiasouza@yahoo.com

3 Discente do Curso de Medicina Veterinária, UFAC, Rio Branco, AC, Brasil. E-mail: medv.lima18@gmail.com

4 Prof ${ }^{a}$ M.e, UFAC, Rio Branco, AC, Brasil. E-mail: patriciafnuness@yahoo.com.br

Author for correpondence 
no hemograma evidenciou o parasitismo nos animais na primeira coleta. Na segunda coleta houve diminuição da presença de eosinófilos e também a quase completa eliminação de ovos e oocistos nos exames coproparasitológicos. O vermífugo utilizado demonstrou um efeito aceitável no manejo sanitário e o hemograma mostrou coerência com o estado de higidez dos animais.

Palavras-chave: Animal silvestre. Endoparasitas. Hemograma.

\section{Introduction}

The paca (Cuniculus paca) has been indiscriminately hunted for its tasty meat, and the over-hunting of the animal may cause extinction (Mittermeier, Schwarz, \& Ayres, 1992). Paca is a great source of protein that is commonly consumed in the Amazon, and captive breeding of the paca is an alternative that can safeguard the species and yield profit due to the high value of meat and animal products (Souza, Santos, \& Campos, 2014).

It is generally accepted that the meat of wild animals is rich in proteins and low in fat, which are qualities sought by consumers who further stimulate the demand (Pinto, Ponsano, Almeida, Heinemann, \& Souza, 2007; Alves, 2009). This is only suppressed by illegal markets that stimulate predatory hunting and threaten the extinction of several species (S. L. G. Nogueira \& Nogueira, 2000). Currently, rearing and commercialization is governed by the IBAMA normative instruction $n^{\circ} 07 / 2015$, which makes the rearing and commercialization of pacas feasible and legal (Instituto Nacional do Meio Ambiente e dos Recursos Naturais Renováveis [IBAMA], 2015).

Parasitosis is one of the most substantial obstacles for the captive rearing of wild animals. The morbidity and mortality of infected or infested animals is directly related to the parasite load, parasite species, host physiological conditions, immunocompetence, and nutritional status (Godoy \& Cubas, 2011).

The reproductive and productive behaviors of the pacas can be affected depending on the load and frequency of the parasite, which can decrease the productivity of the wild species in captivity (Ribeiro, Souza, Mesquita, Alves, \& Santos, 2015).
The scarcity of information on paca rearing discourages rural production. Adequate techniques and application of correct scientific principles would help maintain captivity conditions that approximate the animals' natural environment.

The objective of this study was to perform coproparasitological examinations and hemoparasite investigations associated with blood counts of the parasitized animals before and after deworming. Our results can contribute to the control of parasitism.

\section{Material and Methods}

This study was approved by the Animal Use Ethics Committee of the Universidade Federal do Acre, registered under process number 23107.019896/2017-64 and protocol number 40/2017. The work was conducted in the paca rearing program of the Wild Animal Rearing and Research program - Caboclinho da Mata (IBAMA registry number 509309), located at BR-364, km 30 , in the municipality of Senador Guiomard, Acre $\left(10^{\circ} 03\right.$ '22.2" S, 67³6'03.1" W). The rainy and dry seasons are well defined. June, July, and August were the driest months, with precipitations below 45 $\mathrm{mm}$. The wettest months were December, January, and February.

We used 20 animals, 10 males and 10 females, aged from 2 to 10 years, weighing 7 to $10 \mathrm{~kg}$, identified by microchips, and kept in $12 \mathrm{~m}^{2}(3 \mathrm{~m} \times 4$ $\mathrm{m})$ stalls. We studied 10 stalls in which the animals were not homogeneously allocated.

All animals were initially evaluated for parasite load (heme and endoparasites) using feces samples for the coproparasitological tests and blood samples for complete blood count (CBC). Once the parasitic 
load was defined, we orally dewormed the animals by applying $3 \mathrm{~mL}$ of albendazole + cobalt using a dosing gun (Day 0). After 30 days, we performed a new sampling of feces and blood to repeat the analyses (Day 30).

The animals were captured using nets and physically contained without chemical containment. We collected approximately $2 \mathrm{~mL}$ of blood from the animals through the venipuncture of the cephalic vein, medial saphenous vein, or saphenous vein with $21 \mathrm{G}$ disposable scalps and $5 \mathrm{~mL}$ syringes. The sampling site was sanitized with a cotton swab moistened with $70 \%$ alcohol. The blood was stored in EDTA tubes.

The slides containing the smear were stained using the rapid panopticus method and analyzed using a microscope, observing and photographing suspected cases at $100 \times$ magnification. The evaluation of the hemograms indicated the presence of parasitism.

Together with blood samples, we collected feces samples from the stalls where the animals were kept. The feces were carefully collected in the early hours of the morning to obtain fresh stool uncontaminated with soil material. We collected approximately 20 $\mathrm{g}$ from each stall and stored them in low plastic containers with MIF (Merthiolate-Iodo-Formol) which were labeled and refrigerated in iceboxes for later laboratory analysis.

We analyzed the feces using the Willis Technique (Flotation Technique) to determine light eggs using a hyper-saturated saline solution and sugar and the Hoffmann technique (sedimentation technique) to determine heavy eggs (Melo, Bevilaqua, Selaive, \& Girão, 1998). The reading was performed under optical microscopy with a LEICA DM 750 microscope at a magnification of 20x and 40x. The eggs and oocysts were identified and recorded for further evaluation.
We determined the degree of egg infestation on the slides according to Santos, Oliveira, Vaughan, \& Santiago, (2011). One to three eggs per slide was light $(+)$, four to 10 eggs was moderate $(++)$, and more than 10 eggs was a severe infestation $(+++)$.

We used the t-test for dependent samples (paired t-test) as a statistical methodology, and the significance threshold was $p=5 \%$.

\section{Results and Discussion}

The first samples indicated that $70 \%$ and $90 \%$ of the investigated stalls showed some endoparasite infection in the sedimentation and flotation coproparasitological examinations, respectively. A high rate of parasitized animals is expected in the rainy season when the study was conducted (November to December) due to the higher occurrence of endoparasites during the rainy season (Chaia \& Pauline, 1962; Azevedo, Alves, \& Sales, 2008).

We observed a high level of parasites in the animals according to the classification described by Santos et al. (2011) (Table 1). This occurred despite the sanitary management adopted by the nursery, where the animals are dewormed at least twice a year (Table 1). Trichuris spp., Strongyloides spp., and Eimeria spp. oocysts were detected during the egg identification (Figure 1) (Table 1). These results were already observed in the study conducted by Ribeiro et al. (2015) at the same farm. Santos et al. (2011) found similar results for gastrointestinal eggs and oocysts in capybara also in the state of Acre.

The most common parasite egg in our study was Trichuris spp., with a mean of approximately 13 eggs found per stall. In contrast, a higher incidence of Strongyloides spp. was found in the coproparasitological examinations in a study conducted by Ribeiro, Carvalho, Peruquetti, Medeiros and Freitas (2017). 


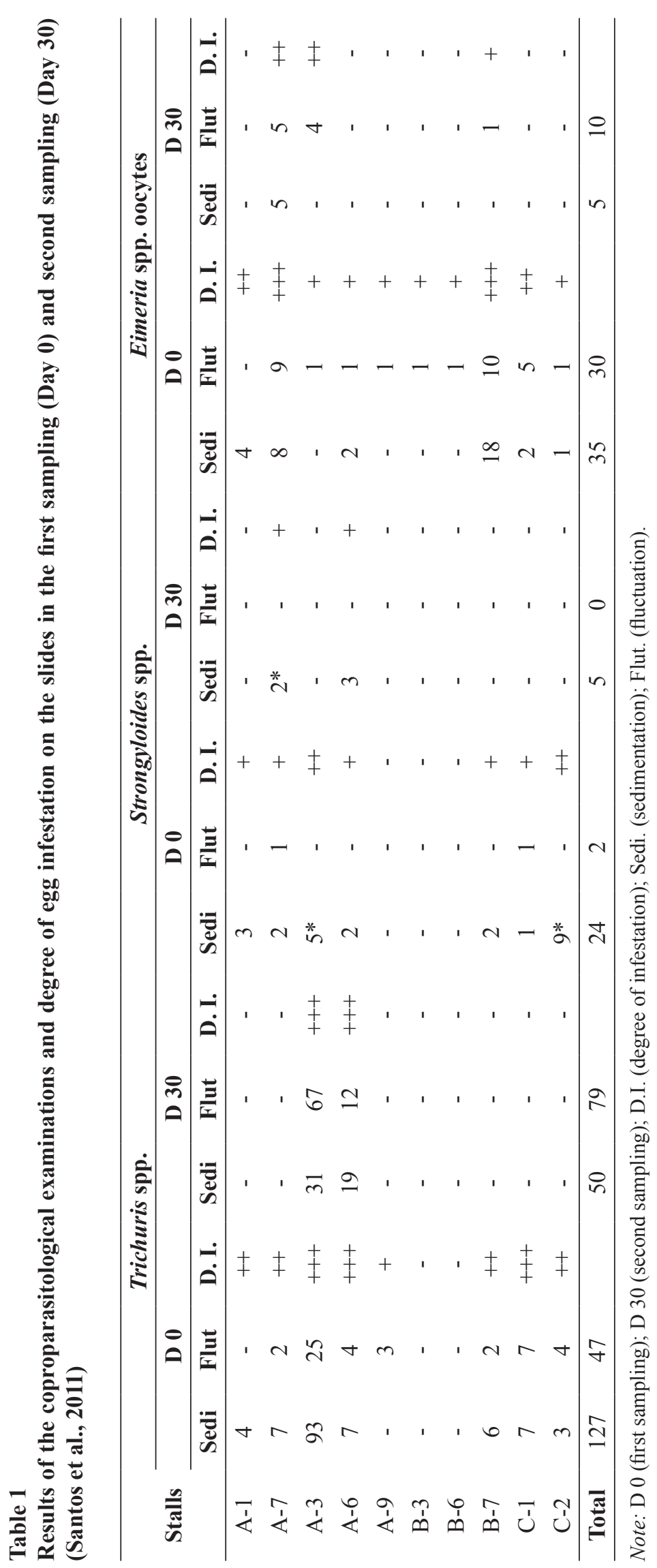




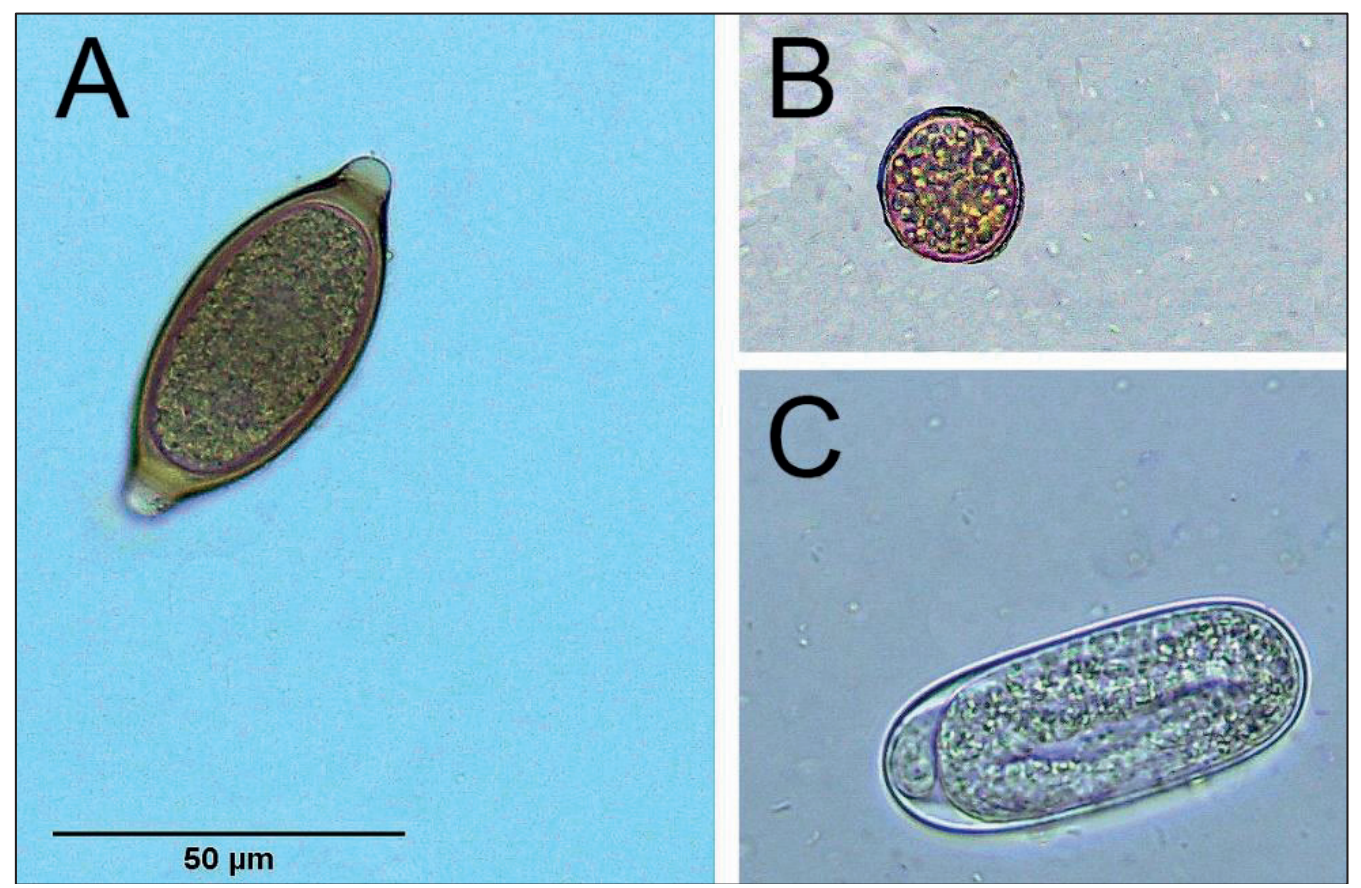

Figure 1. Trichuris spp. egg (A); Eimeria spp. oocyte (B); Strongyloides spp. egg (C), magnification of $20 \times$ and $40 \times$.

Regarding the hematological levels obtained in the first sampling, we observed eosinophilia and leukocytosis in the animals individually. This probably demonstrates an infection by endoparasites, and similar results were found in the study conducted by Silva, Freire, Silva and Amarante, (2010) in dogs. However, the hematocrit and total protein values were within the reference range based on the patterns reported in the studies conducted by T. R. M. Nogueira, (1997) and Stradiotti et al. (2015).

We found no hemoparasite specimens in the thin smears, but Urquhart, Armour, Duncan, Dunn and Jennigs (1998) argue that trypanosomiasis is basically a wild animal infection that has acquired a modus vivendi since animal hosts are parasystemic for long periods.

In the second sampling, the results of the flotation and sedimentation coproparasitological examinations revealed that $60 \%$ and $70 \%$ of the stalls presented noninfected animals, respectively.
However, two stalls still presented a considerable number of Trichuris spp. (Table 1). The degree of infestation according to Santos et al. (2011) also demonstrated this decrease in parasite infestation (Table 1). Parasitism in some animals even after deworming may be due to very high age (more than 10 years), as was the case of the animals of the stall in question. This may be due to natural immunosenescence caused by the age of the animals (Esquenazi, 2008).

The second sampling $\mathrm{CBC}$ detected reduced eosinophilia, which was more commonly observed in males. Stradiotti et al. (2015) observed that the eosinophil levels changed in relation to the sex of the animal, presenting higher values in females. This contrasted with the results from this study where the eosinophil levels were higher in males. We also verified the decrease of eosinophils in the leukogram when evaluating the results of the second blood sampling (Table 2). It was impossible to establish a relationship between the hematological 
parameters and parasitism since the fecal samples did not present the same sample unit. While the hematological parameters were obtained from blood collected from individual animals, the feces pooled into a single sample from multiple animals in one stall. Even after the parasitosis decreased, the mean leukocyte values were higher compared to the values found by T. R. M. Nogueira (1997) and Stradiotti et al. (2015) (Table 2). This is probably due to stress during sampling. Stradiotti et al. (2015) and T. R. M. Nogueira (1997) used chemical containment when collecting the samples. Here, we only used mechanical restraints, possibly generating a "stress blood count" in the examinations. The leukocytes (segmented neutrophils) of the marginal pool can be mobilized using adrenaline, putting them into circulation. This could increase the leukocytes in the total count, explaining the high values in the means obtained especially in young animals (Swenson, 1993; T. R. M. Nogueira 1997). We found no other discrepant changes in the hemogram results and in the leukocyte differential (Table 2). The hematocrit remained unchanged compared to the first sampling, presenting values slightly superior to the normality standards presented by T. R. M. Nogueira (1997) and Stradiotti et al. (2015). Most domestic animals have hematocrit values ranging from 38 to $45 \%$ with a mean of $40 \%$. Excitation leading to the release of erythrocytes by the spleen, asphyxia, or dehydration can lead to hemoconcentration, resulting in high values that are variable when compared to the standards (Swenson, 1993; T. R. M. Nogueira, 1997). T. R. M. Nogueira (1997) stated that young male pacas are more excitable when captured with nets, which may be responsible for the slightly higher hematocrit values in this group.

The hematological values of the first sampling did not differ much from the values of the second sampling, which were slightly higher in males and lower in females with a $\mathrm{p}$ value $=5 \%$. Table 3 describes a pattern of the white series and hematocrit obtained from pacas unanesthetized for the blood sampling procedure, demonstrating that $\mathrm{n}=40$ is quite important as a number of samples. It should be considered that the values were higher in unanesthetized animals, obtaining high values compared to the literature. This is because T. R. M. Nogueira (1997) Stradiotti et al. (2015) obtained their hematological values from previously anesthetized animals. Even with the hematological parameters being uninfluenced by parasitism, the decrease in the parasites in the coproparasitological tests lead us to believe that deworming with albendazole + cobalt yielded the expected results according to the statistics (Figure 2).

\section{Table 2}

Comparison between the hematological parameters and the respective standard deviation

\begin{tabular}{|c|c|c|c|c|c|c|c|c|}
\hline \multirow[t]{2}{*}{ PARAM. } & \multicolumn{2}{|c|}{ NOGUEIRA (1997) } & \multicolumn{2}{|c|}{ STRADIOTTI (2015) } & \multicolumn{2}{|c|}{ RESEARCH DAY 0} & \multicolumn{2}{|c|}{ RSEARCH DAY 30} \\
\hline & MALE & FEMALE & MALE & FEMALE & MALE & FEMALE & MALE & FEMALE \\
\hline & $3.78 \pm$ & & & & & & & \\
\hline & $\begin{array}{c}10,493 \pm \\
3,208\end{array}$ & $\begin{array}{c}9,570 \pm \\
1,844\end{array}$ & $\begin{array}{c}9,120 \pm \\
3,160\end{array}$ & $\begin{array}{c}10,820 \pm \\
2,170\end{array}$ & $\begin{array}{c}14,035 \pm \\
6,216\end{array}$ & $\begin{array}{c}13,460 \pm \\
4,227\end{array}$ & $\begin{array}{c}15,105 \pm \\
3,188\end{array}$ & $\begin{array}{c}11,250 \pm \\
5,814\end{array}$ \\
\hline Hematoc. & $42.98 \pm 6.74$ & $40.31 \pm 4.51$ & $44.20 \pm 4.2$ & $39.2 \pm 4.2$ & $46 \pm 5.65$ & $42 \pm 5.59$ & $45 \pm 3.94$ & $42.1 \pm 6.40$ \\
\hline
\end{tabular}


Table 3

Hematological profile of pacas unanesthetized for blood sampling. The samples derived from animals maintained in captivity

\begin{tabular}{cccc}
\hline Blood cell count & Mean & Standard deviation & n \\
\hline Total leucocytes & 13452.50 & 5022.309 & 40 \\
Lymphocytes (\%) & 0.82 & 0.162 & 40 \\
Segmented Neutrophils (\%) & 0.11 & 0.079 & 40 \\
Eosinophils (\%) & 0.02 & 0.017 & 40 \\
Bands (\%) & 0.01 & 0.013 & 40 \\
Monocytes (\%) & 0.01 & 0.039 & 40 \\
Hematocrit (\%) & 0.44 & 0.056 & 40 \\
\hline
\end{tabular}

nd $40 \times$.

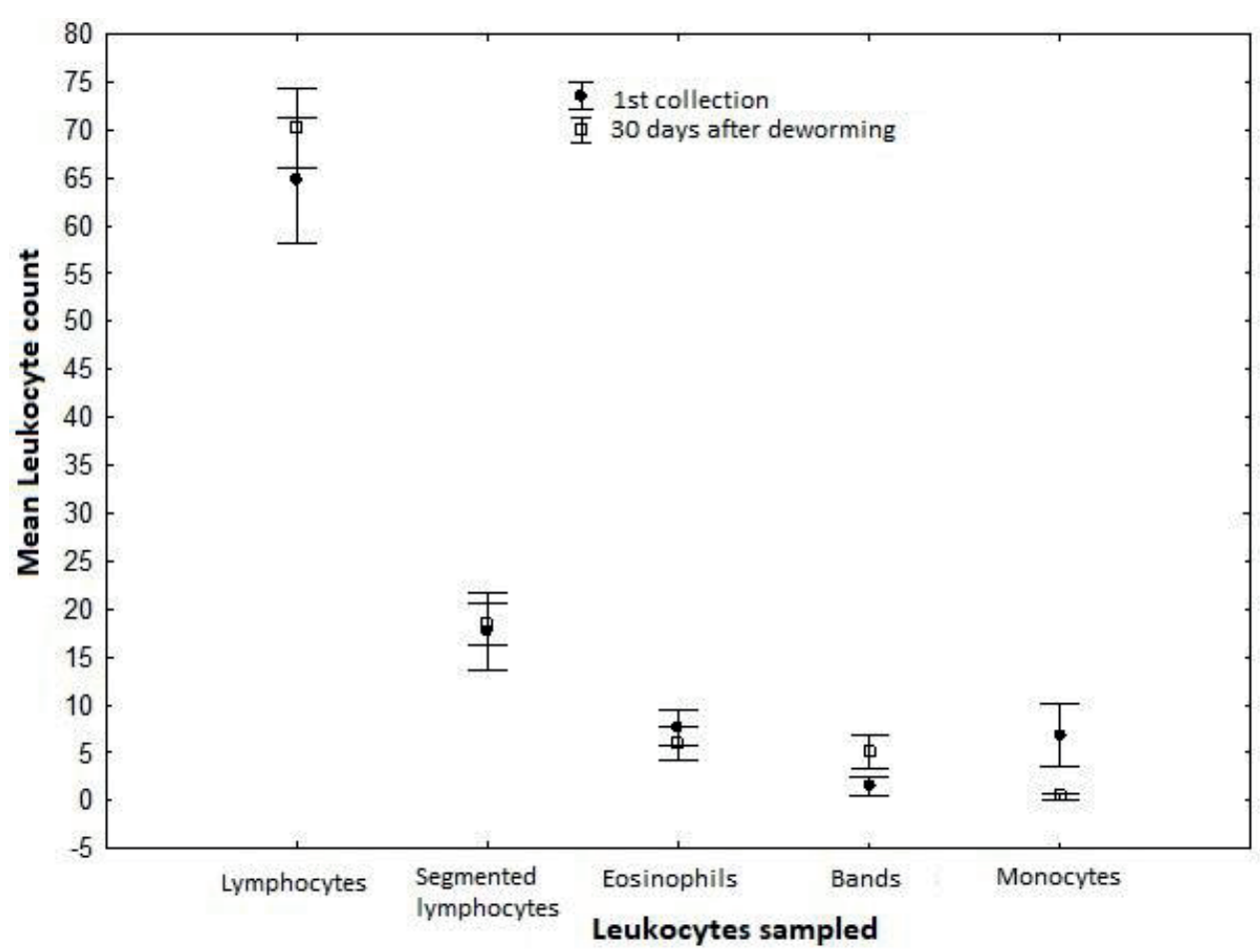

Figure 2. Statistical comparison between the first and the second blood samplings from unanesthetized pacas reared in captivity to demonstrate parasitism.

\section{Conclusion}

We obtained the highest prevalence of Trichuris spp. in the studied animals. Based on this, the vermifuge was effective. However, stall cleaning, disinfection, caution during mating, and animal stall exchanges must be performed daily. Despite the determination of endoparasitism in a batch factory, there was no association with hematological alterations. This is probably due to the number of blood samples tested and the stool collection method. CBC was consistent with the state of animal hygiene and corroborated to improve endoparasite control measures. However, the blood sampling is complicated because animals are stressed and injured due to the restraints. 
Because these are pioneering studies using unanesthetized animals for blood sampling, hematological pacing patterns have not yet been fully elucidated. Additional studies over a longer period of time with more samples are required to standardize these values.

\section{References}

Alves, R. O. (2009). Criação, abate e comercialização de animais silvestres. Trabalho de Conclusão de Curso especialização em Vigilância Sanitária e Controle da Qualidade dos Alimentos, Universidade Castelo Branco, Brasília, DF, Brasil.

Azevedo, D. M. M. R., Alves, A. A., \& Sales, R. O. (2008). Principais ecto e endoparasitas que acometem bovinos leiteiros no Brasil: uma revisão. Revista Brasileira de Higiene e Sanidade Animal: RBHSA, 2(4), 43-55.doi: 10.5935/1981-2965.20080003

Chaia, G, \& Pauline, E. (1962). Ação do 0,0-Dimetilfosfato do 1-Hidroxi-2,2,2-Tricloro-Etila (Dipterex) Sobre as larvas de Strongyloides Ratti e Strongyloides Stercoralis. Revista do Instituto de Medicina Tropical de São Paulo, 4(4), 256-260.

Esquenazi, D. (2008). Imunossenescência: as alterações do sistema imunológico provocadas pelo envelhecimento. Revista Hospital Universitário Pedro Ernesto, 1(1), 38-44.

Godoy, S. N. \& Cubas, Z. S. 2011. Doenças virais e parasitárias em Psittaciformes: uma revisão. Clínica Veterinária, 90, 32-44.

Instituto Nacional do Meio Ambiente e dos Recursos Naturais Renováveis. (2015). Epi Info. Retrieved from http://www.ibama.gov.br/phocadownload/ fauna/faunasilvestre/2015_ibama_in_07_2015 autorizacao_uso_fauna_empreendimentos.pdf.

Melo, A. C. F. L., Bevilaqua, C. M. L., Selaive, V., \& Girão, M. D. (1998). Resisgência a anti-helmínticos em nematóides gastrintestinais de ovinos e caprinos, no municipio de Pentecoste, Estado do Ceará. Ciência Animal, 8(1), 7-11.

Mittermeier, R. A., Schwarz, M., \& Ayres, J. M. (1992). A new species of marmoset, genus Callithrix Erxleben, 1777 (Callitrichidae, Primates) from the Rio Maues region, state of Amazonas, central Brazilian Amazonia. Goeldiana Zoologia, 14, 1-17.

Nogueira, S. L. G., Fo, \&Nogueira, S. S. (2000). Criação comercial de animais silvestres: produção e comercialização da carne e de subprodutos na região sudeste do Brasil. Revista Econômica do Nordeste, 31(2), 188-195.

Nogueira, T. M. R.(1997). Alguns parâmetros fisiológicos e reprodutivos da paca (Agouti paca, Linnaeus, 1766), em cativeiro. Dissertação (Mestrado) Universidade Estadual Paulista, Jaboticabal, SP, Brasil.

Pinto, M. F., Ponsano, E. H. G., Almeida, A. P. D. S., Heinemann, R. J. B., \& Souza, W. M. D. (2007). Características e potencial tecnológico da carne da capivara. Ciência Rural, 37, (3), 868-873. doi: $10.1590 / \mathrm{S} 0103-84782007000300041$.

Ribeiro, V. M. F., Carvalho, Y. K. de, Peruquetti, R. C., Medeiros, L., \& Freitas, H. J. de. (2017). Consumo e comercialização de carnes silvestres: potencial econômico para a Amazônia Ocidental. Journal of Amazon Health Science, 2(1), 1-8.

Ribeiro, V. M. F., Souza, S. F. de, Mesquita, N. M. P. de, Alves, A. L. F., \& Santos, F. G. de A. (2015). Acompanhamento da carga parasitária intestinal e do manejo sanitário de um criatório de pacas. Ciência Animal Brasileira, 16(4), 608-614. doi: 10.1590/1089-6891v16i432406.

Santos, T., Oliveira, J. B. de, Vaughan, C., \& Santiago, H. (2011). Health of an ex situ population of raptors (Falconiformes and Strigiformes) in Mexico: diagnosis of internal parasites. Revista de Biologia Tropical, 59(3), 1265-1274. doi: 10.15517/rbt. v0i0.3397.

Silva, B. J. D. A., Freire, I. M. A., Silva, W. B. da, \& Amarante, E. E. V. G. do. (2010). Avaliação das alterações hematológicas nas infecções por helmintos e protozoários em cães (Canis lupus familiaris, Linnaeus, 1758). Neotropical Helminthology, 4(1), $37-48$.

Souza, B. C. S., Santos, G. A., \& Campos, R. M. L. (2014). Carne de jacaré. Revista Eletrônica Nutritime, 11(6), 3741-3754.

Stradiotti, C. G. P., Lopes, G. L., Stradiotti, D., Jr., Cóser, A. C., Rangel, C. C., Rodrigues, T. F.,... Almeida, F. M. (2015. Estudos hematológicos em pacas sob condições de cativeiro. Revista Brasileira de Medicina Veterinária, 37(3), 227-232.

Swenson, M. J. (1993). Propriedades fisiológicas e constituintes químicos e celulares do sangue. In $\mathrm{H}$. H. Dukes. Fisiologia dos animais domésticos (Chap. 2, pp. 19-43). Rio de Janeiro: Guanabara Koogan.

Urquhart, G. M., Armour, J., Duncan, J. L., Dunn, A. M., \& Jennigs, F. W. (1998). Parasitologia veterinária (2a ed.). São Paulo: Guanabara Koogan. 